\title{
PERCEPTIONS OF CORPOREAL DIMENSION OF BEAUTY IN VARIOUS DISCOURSES OF THE RUSSIAN LINGUOCULTURE
}

\author{
Viktoriya V. Zhura \\ Volgograd State Medical University, Volgograd, Russia \\ Yuliya V. Rudova \\ Volgograd State Medical University, Volgograd, Russia
}

\begin{abstract}
The article set out to explore the ways in which the corporeal dimension of beauty is represented in medical and internet discourses of the Russian linguoculture. The importance of the phenomenon being studied is associated with a significant role of the corporeal dimension in constructing the linguistic world view and building language awareness of the Russian-language homo communicans. Using the explanatory potential of the word 'concept' we identified that the corporeal dimension is formed by semantic, axiological and imagery components and is incorporated into the Beauty concept. The medical discourse provides an objective presentation of the morphological parameters of the body, which can be graduated on the basis of mathematical symbols. Within the internet discourse, corporeal beauty is subjectively interpreted and is conceptualized as changeable, achievable, natural and a launch pad to success. The axiological component is conceptualized in the studied discourses in various ways. Within the medical discourse, the corporeal dimension correlates with the physiological norm, while in the internet discourse it is associated with evaluation statements of the Russian linguoculture. The imagery is conceptualized by means of icons in both discourses. The findings of the study, which shed light on the ways the corporeal dimension of the Beauty concept is represented in different discourses, may become a tool for elucidating the patterns of verbal behavior associated with aesthetic appreciation, and a means of facilitating intercultural communication.
\end{abstract}

Key words: corporeal dimension, medical discourse, internet discourse, semantics, axiology, imagery, the Beauty concept.

Citation. Zhura V.V., Rudova Yu.V. Perceptions of Corporeal Dimension of Beauty in Various Discourses of the Russian Linguoculture. Vestnik Volgogradskogo gosudarstvennogo universiteta. Seriya 2. Yazykoznanie [Science Journal of Volgograd State University. Linguistics], 2019, vol. 18, no. 4, pp. 118-128. (in Russian). DOI: https://doi.org/10.15688/jvolsu2.2019.4.9

УДК 811.161 .1 '42

ББК $81.411 .2-51$

Дата поступления статьи: 14.03.2019

Дата принятия статьи: 03.09.2019

\section{КОРПОРЕАЛЬНОСТЬ И ПРЕДСТАВЛЕНИЯ О КРАСОТЕ В РАЗЛИЧНЫХ ДИСКУРСАХ РУССКОЙ ЛИНГВОКУЛЬТУРЫ}

\section{Виктория Валентиновна Жура}

Волгоградский государственный медицинский университет, г. Волгоград, Россия

\section{Юлия Владимировна Рудова}

Волгоградский государственный медицинский университет, г. Волгоград, Россия

\footnotetext{
Аннотация. Целью исследования стало выявление особенностей репрезентации признака корпореальности в контексте представлений о красоте, реализованных в русской лингвокультуре в медицинском и интернет-дискурсах. Актуальность работы обусловлена значимой ролью корпореальности в картировании действительности в сознании русской языковой личности. С использованием объяснительного потенциала тер-
} 
мина «концепт» показано, что корпореальность формируется понятийной, ценностной (оценочной) и образной составляющими и входит в структуру концепта «Красота». В медицинском дискурсе понятийный компонент корпореальности включает объективные представления о морфологических параметрах тела и их градуируемости при помощи математических единиц. В интернет-дискурсе актуализируются субъективные признаки телесной красоты: ее изменчивость, отчуждаемость, естественность и роль в повышении социального статуса. Ценностный компонент по-разному реализуется в изучаемых дискурсах: путем соотнесения с физиологической нормой в медицинском дискурсе и оценочными понятиями русской лингвокультуры в интернет-дискурсе. Образный компонент в обоих дискурсах реализуется посредством иконических знаков. Полученные в работе выводы об особенностях репрезентации корпореальности концепта «Красота» в различных дискурсах могут быть использованы для объяснения закономерностей вербального поведения людей при оценке объектов эстетического восприятия, а также для облегчения межкультурного взаимодействия.

Ключевые слова: корпореальность, медицинский дискурс, интернет-дискурс, понятийный компонент, ценностный компонент, образный компонент, концепт «Красота».

Цитирование. Жура В. В., Рудова Ю. В. Корпореальность и представления о красоте в различных дискурсах русской лингвокультуры // Вестник Волгоградского государственного университета. Серия 2, Языкознание. - 2019. - Т. 18, № 4. - C. 118-128. - DOI: https://doi.org/10.15688/jvolsu2.2019.4.9

\section{Введение}

Освоение действительности человеком осуществляется на основе взаимосвязи его физической и духовной сущностей. Именно поэтому красотой наделяются не только объекты внешнего мира, но и телесные «параметры» индивида, а также его духовные (душевные) качества. В связи с этим актуально изучение корпореальности как важнейшей характеристики культуры в целом и той или иной лингвокультуры в частности. Поскольку корпореальность является важным признаком, на котором базируется концептуализация действительности и который определяет способы конструирования внешнего мира человеком, значимым представляется выявление особенностей выражения корпореального признака, входящего в структуру концепта «Красота» и по-разному эксплицированного в дискурсах разных типов, репрезентирующих русскую лингвокультуру.

\section{Методы и методология исследования}

В данном исследовании использовано понятие концепта, широко применяемое в лингвистике и лингвокультурологии и до сих пор имеющее эвристический потенциал. Термином «концепт» в данной работе обозначена ментальная единица упорядочения информации об особенностях восприятия и объективации социокультурно значимых фрагментов действительности. Учитывая тот факт, что концепт - это культурно-специфический конструкт, возникающий в сознании и приобретающий дополнительные смыслы, образы и оценки в условиях изменяющейся объективной действительности, в работе мы придерживались определения концепта, данного В.И. Карасиком: «Концепт - это многомерное смысловое образование, в котором наряду с образно-перцептивной и понятийной составляющими, выделяется ценностный компонент» [Карасик, 2001, с. 10]. Компоненты концепта получают формальную репрезентацию при помощи вербальных и невербальных средств, эксплицитно или имплицитно передающих его содержание.

Выявление и описание корпореального признака исследуемого концепта осуществлялось на основе метода концептуального анализа. Изучение способов репрезентации корпореальности проводилось с применением методов интерпретативного и лингвистического анализа медицинского дискурса и интернетдискурса.

Лексико-семантический анализ слов, репрезентирующих концепт «Красота», проведенный рядом исследователей на материале словарных статей толковых словарей (см., например: [Колышкина, Шустина, 2015; Окунева, 2008; Черкашина, 2014]), позволил установить, что корпореальность является ядерным понятийным признаком данного концепта, так как в различных словарных источниках облигаторно фиксируется значение, связанное с красо- 


\section{РАЗВИТИЕ И ФУНКЦИОНИРОВАНИЕ РУССКОГО ЯЗЫКА}

той человека, его внешности в целом либо лица, осанки, глаз и т. п.

В качестве рабочей гипотезы было сформулировано предположение о том, что реализация признака корпореальности зависит от типа дискурса, в котором репрезентируется концепт «Красота». Исследование проведено на материале медицинского дискурса и интернет-дискурса в таких его разновидностях, как медико-эстетический и модельный дискурс (о принципах выделения этих разновидностей (см.: [Ахнина, Куриленко, 2015; Михеев, Горбунов, 2012; Пивоварчик, 2018]). Выбор этих типов дискурса обусловлен центральной ролью понятия «тело» и его внешних признаков в их концептуальной системе, а также различными подходами к их концептуализации. В рамках каждого дискурса выявлены вербальные и невербальные средства реализации понятийной, образной и оценочной составляющих корпореальности в структуре концепта«Красота».

\section{Результаты и обсуждение}

Медицинский дискурс. Тело человека является важнейшим объектом изучения и воздействия в медицине. Первые попытки научного анатомического определения идеальных пропорций человеческого тела были предприняты в Древней Греции. Создавая статуи богов, скульпторы выявили математическое соотношение размеров частей тела, которое они соблюдали в своих произведениях. Дальнейшей попыткой обоснования канонических анатомических параметров тела человека стало созданное Леонардо да Винчи изображение Витрувианского человека и пояснительные надписи к нему. На основании этого рисунка также были сделаны выводы об идеальных геометрических и арифметических параметрах тела.

Современный уровень развития медицины позволяет более детально описать телесные параметры человека. В рамках медицинского дискурса концепт «Красота» реализуется посредством набора морфологических признаков, определяющих форму тела человека. Значения каждого из признаков могут варьироваться в определенном диапазоне, поэтому понятийная составляющая рассмат- риваемого концепта включает, как правило, значения, соотносимые с наиболее удовлетворительными показателями физиологической жизнедеятельности организма. К числу основных морфологических признаков относятся следующие: длина тела человека (рост), периметр (обхват) груди, масса тела, пропорции тела, телосложение, включающее развитие мускулатуры, жироотложений, форму грудной клетки, форму живота и т. д. (Ёкубов, Болтаева). Норма морфологического признака получает выражение при помощи математических обозначений (Филимонова и др.).

Лицо человека в медицине также описывается в терминах ряда морфометрических признаков: высота лба, ширина лба, высота носа, скуловой диаметр и др. Морфологическая типология лица имеет этноспецифический характер и, кроме того, отражает взаимосвязь между отдельными параметрами лица и половым диморфизмом (Негашева; Хлыбов и др.).

Соответствие морфометрических параметров лица нормативным критериям определяется на основе их роли в осуществлении физиологических процессов, а отклонение от нормы рассматривается в связи с различными патологическими состояниями (например, уменьшением высоты гнатической части лица или ухудшением окклюзии зубов) (Королев и др.).

Итак, понятийная составляющая корпореальности концепта «Красота» в медицинском дискурсе включает семантические признаки морфологии тела человека, которые репрезентируются при помощи медицинских терминов. Оценочная составляющая получает двоякое выражение: с одной стороны, при помощи математического градуирования выделенных параметров, с другой стороны, посредством соотнесения проградуированных параметров с нормальным функционированием человеческого организма. Следовательно, в медицинском дискурсе понятие красоты коррелирует с понятием нормы и соответствием ей и наоборот. Примером тому может послужить описание астенического типа телосложения:

(1) Он отмечал у астеников высокий рост, лептосомное телосложение, узкую грудную клетку, подвижное десятое ребро, слаборазвитую муску- 
латуру, склонность к побледнению кожи (Цыганков, Овсянников, с. 95);

(2) У астеников определяют тонкую аорту, сплахноптоз, слабость связок, сухожилий и соединительной ткани. < .. > Это слабое развитие поперечного размера проходит через все части тела... и через все формы тканей (Цыганков, Овсянников, с. 95).

Отрицательно-оценочные дескрипторы слаборазвитая, побледнение, слабость свидетельствуют о несоответствии такого тела нормам физического здоровья, а соответственно, красоты.

Анализ текстов медицинских статей, монографий и учебных пособий, трактующих базовые медицинские понятия, показал, что образная составляющая корпореальности концепта «Красота» в медицинском дискурсе не находит объективации посредством вербальных средств. Тем не менее, в ряде случаев научный текст сопровождается рисунками, схемами, диаграммами или графиками, иллюстрирующими образную составляющую описываемых телесных параметров, что позволяет говорить о его частичной креолизации знаками отличных от естественного языка семиотических систем (см. об этом процессе: [Саидова, 2016]). Итак, представления о корпореальности красоты конструируются в медицинском дискурсе на основании медицинской картины мира, и в соответствии с ее критериями текстовую репрезентацию получают оценочная и образная составляющая описываемого нами признака.

Интернет-дискурс. Для изучения способов объективации корпореального признака концепта «Красота» в медико-эстетическом интернет-дискурсе мы провели анализ вербального оформления сайтов клиник косметологии и пластической хирургии («Вирго», «Врачебная косметология», «Lege Artis», «СМ-Косметология», «Лазерный доктор», «Градиент» и др.).

В медико-эстетическом дискурсе понятийная составляющая корпореальности конструируется посредством выражения как эстетических, так и медицинских признаков. Для репрезентации эстетических признаков красоты используется «метод от противного», то есть перечисление физических несовершенств облика человека, которые будут преодолены в случае обращения в клинику (второй под- бородок, рубиы и растяжки, иеллюлит, морщиныь, борозды «гнева» на лбу и т. п.). Отсутствие этих и других дефектов постулируется как красота. Намечается и траектория достижения красоты, вербализуемая посредством предикатных конструкций:

(3) С помощью процедур биоревитализации можно: увлажнить кожу; выровнять рельеф кожи; устранить морщины и дряблость кожи (ВМЭЦ).

Необходимо отметить, что оба смысловых компонента (наличие телесных дефектов и способы их устранения, а точнее достигнутый результат, находятся на разных оценочных полюсах концепта «Красота», то есть сопряжены с ценностной составляющей концепта.

Медицинские аспекты корпореальности как в медицинском, так и в медико-эстетическом интернет-дискурсе акцентируют физиологическую норму протекания процессов в организме. Описания различных косметологических процедур по достижению красоты включают указание на нормализацию / оптимизацию физиологических процессов, протекающих в организме:

(4) [при RF-лифтинге лица и тела] улучшается снабжение клеток кислородом (ВМЭЦ);

(5) [при мезотерапии] усиливается кровообращение, ускоряются обменные процессы, быстрее идет обновление клеток») (ВМЭЦ).

Предоставление подобной информации позволяет «усилить» эстетические параметры искомой красоты путем указания на ее физиологичность.

В медико-эстетическом дискурсе актуализацию получает и такой понятийный аспект красоты, как изменчивость. Красота представляется как нечто отчуждаемое, как то, что может приноситься извне, корректироваться в угоду моде:

(6) Ведь концепция идеальной красоты и Ваше лицо подвержены постоянным изменениям, поэтому потребности и запросы подлежат периодической корректировке (ВКМЭЦ).

Схожая с этой интерпретация понятия красоты содержится в отзывах клиентов клиник косметологии: 
(7) Моя красота в руках профессионалов! (ВМЭЦ).

Кроме того, в объем понятия корпореальной красоты включаются привносимые извне атрибуты физического совершенства перманентный макияж, пирсинг, шугаринг, татуировки и т. п., которым придается положительная оценка:

(8) Перманентный макияж (татуаж) сохраняет четкость линий макияжа... значительно экономит время (ВКМЭЦ);

(9) Пирсинг является своеобразным искусством, которое требует вторжения в тело человека (ВКМЭЦ).

Анализ информации, представленной на сайтах клиник, показал, что ценностный аспект телесной красоты реализуется в медико-эстетическом дискурсе посредством апелляции к таким ценностным понятиям, как молодость, совершенство, безболезненность и безвредность для организма. Они сопряжены с положительной оценкой и в совокупности отражают идеал человеческой красоты: обладание молодостью или ее продление, оптимальное состояние физической внешности и физиологии, отсутствие болезни и боли. Примером экспликации такой оценки служат описания различных процедур, акцентирующие данные аспекты корпореальной красоты: омоложение кожи, разглаживание кожи, формирование тургора, обновление кожи (ВМЭЦ). В медико-эстетическом интернетдискурсе происходит ценностная гиперболизация ряда морфологических признаков, которые рассматривались нами в рамках медицинского дискурса. Так, если в медицинском дискурсе общая величина лица толкуется как признак, позволяющий дифференцировать женские и мужские особи (половой диморфизм), то в рамках медико-эстетического интернет-дискурса его гносеологический потенциал заменяется на аксиологический (форма и овал лица рассматриваются как признаки фемининности / маскулинности, то есть красоты). В медико-эстетическом интернет-дискурсе ценностное значение может переноситься и на другие морфологические признаки для акцентирования женственности (пухлые губы, узкие и высокие скулы с отсутствием комков Биша, острый подбородок) или мужественности:

(10) Любая модница желает иметь высокие скулы. Кто-то, следуя диктуемой с запада моде, мечтает о скулах, как у голливудских звезд - как правило, высоко приподнятых и резко очерченных. Но самые утонченные соискательницы знают, что секрет воспеваемой красоты русской женщины заключается в мягкости и большей женственности черт лица, типичных для восточных славянок. Поэтому все большей популярностью пользуются высокие, мягко очерченные, женственные - «славянские» скулы. Высокие скулы - это не только модно и красиво. Поднятие скул поможет визуально скрыть некоторые недостатки, к примеру, круглое лицо сделать более узким (LA).

В медицинском дискурсе эти признаки не обладают такой понятийной причинно-следственной связью:

(11) Скуловая кость - парная, является одной из наиболее крепких. Она имеет неправильную четырехугольную форму. Эта кость легко прощупывается под кожей. Она соединяется с лобной, клиновидной, височной костями и верхней челюстью. От формы скуловой кости в значительной мере зависит форма средней части лица» (Иваницкий, с. 80).

В ряде случаев данные признаки противоречат представлению о физиологической норме (например, липосакция на бедрах, преследующая цель уменьшить объем бедер у представительниц женского пола). Кроме того, чрезмерное увлечение процедурами эстетической косметологии и пластической хирургии может приводить к достижению анти-идеала телесной красоты, о чем повествуют нарративы пластических хирургов [Zhura, Rudova, Martinson, 2017].

Образная составляющая признака корпореальности также получает репрезентацию в текстах сайтов клиник косметологии и пластической хирургии и способствует созданию их апеллятивного потенциала. Средствами его репрезентации выступают образные сравнения, метафоры, эпитеты, стилистический прием контраста, способствующие ментальной визуализации явлений:

(12) Можно навсегда забыть о «гусиных лапках» в уголках глаз и губ, о грубых бороздах «гнева» на лбу (ВКМЭЦ); 
(13) Мелкие и глубокие морщины разглаживаются, а поверхность кожи становится ровной (ВКМЭЦ);

(14) появляются сеточки морщин и мешки под глазами (ВКМЭЦ);

(15) появляются ненавистные жировые отложения (ВКМЭЦ);

(16) «апельсиновая корка» и нежелательная растительность (ВКМЭЦ).

Частотным является использование образных медицинских жаргонизмов и профессионализмов:

(17) «Печеночные» пятна, родимые пятна, «старческая гречка», родинки, веснушки, солнечное лентиго - все это гиперпигментация (ВКМЭЦ).

В текстах сайтов осуществляется в основном апелляция к отрицательно-оценочным образам.

Для изучения особенностей объективации корпореального признака концепта «Красота» в модельном интернет-дискурсе мы проанализировали информационный блок о требованиях, предъявляемых к физическим параметрам моделей, на интернет-сайтах российских модельных агентств «Elite Stars», «Krasnadevitsa», «Brio Models», «Sigma».

Анализ лексико-семантического уровня текстов, представленных в информационном блоке «Стать моделью», существующем в структуре всех рассмотренных сайтов модельных агентств, позволил выявить ряд ключевых слов, раскрывающих основной семантический признак телесной красоты - физическое совершенство, отвечающее требованиям модельного бизнеса: идеальная внеиность, идеальное тело, фигура модели, модельная внешность, идеальная фигура, красивое тело.

В рамках описываемой разновидности интернет-дискурса понятийная составляющая признака корпореальности концепта «Красота» реализуется посредством описания привлекательности тела в целом и отдельных его частей. Акцент при этом делается как на природных данных, соответствующих требуемым в модельном бизнесе параметрам, так и на красоте, достигаемой путем сознательных усилий в стремлении к навязываемому идеалу; ср. примеры (18) и (19):
(18) ...Открыть дорогу в мир высокой моды для девушки с идеальными параметрами и чертами лица (RMM);

(19) Тело должно выглядеть красивым, подтянутым, без видимых шрамов и татуировок. Волосы придают особый шарм внешности, если они ухоженные и имеют естественный цвет. Не стоит забывать о внешнем виде ногтей и пяток (BM).

Важным критерием красоты, актуализированным в данном дискурсе, является молодость:

(20) Вы молоды и красивы? Значит, карьера модели - это для вас (AMS).

Несмотря на то что стремление к внешнему совершенству поощряется в данном дискурсе, важным измерением телесной красоты считается ее естественность:

(21) Волосы должны быть живыми, блестящими, шелковистыми. < .. > Ногти должны быть ухожены и естественны... (KM);

(22) Модель должна максимально естественно выглядеть! (КМ);

Кроме того, красота постулируется как способ улучшения качества жизни, повышения статуса, социально-экономического положения:

(23) Начни свое восхождение в глянцевый мир с модельной школой... (AMS);

(24) Попасть в модельный бизнес мечтают ... (AMS);

(25) Не секрет, что модель это тоже профессия и профессия высокооплачиваемая (GMS).

Ценностная составляющая корпореальности реализуется в модельном интернет-дискурсе посредством соотнесения красоты тела с такими положительно оцениваемыми в обществе понятиями, как совершенство, естественность, молодость. Кроме того, подчеркивается, что данные составляющие красоты обеспечивают возможность достижения успеха в жизни, что также характеризует высокую социокультурную значимость корпореального признака:

(26) Мы готовы работать 25 часов в сутки, чтобы вы обрели уверенность и превратили каждый нюанс своей внешности... В ту «фишку», которая превращает модель в успешную модель! (S); 


\section{РАЗВИТИЕ И ФУНКЦИОНИРОВАНИЕ РУССКОГО ЯЗЫКА}

(27) Мы делаем все для того, чтобы мечты о зарубежных контрактах воплощались в жизнь (S).

На вербальном уровне ценностный аспект объективируется при помощи обращений, императивов и модальных выражений, стимулирующих к использованию телесной красоты для достижения успеха, а также применением прилагательных с положительно-оценочной семантикой:

(28) Невозможно вести успешный модельный бизнес без по-настоящему красивых и талантливых ребят (S);

(29) Не бойтесь пробовать, не упускайте свой шанс, нам неважно, из какого вы города, если у вас хорошие внешние данные!!! (S);

(30) Сейчас вы на нашем сайте, а значит, нет повода опускать руки! (S).

Важную роль в реализации оценочного потенциала признака корпореальности играют модальные глаголы и слова, выражающие положительное отношение к сообщаемому и повышающие его аксиологический статус:

(31) В ходе обучения в нашей школе моделей ты сможешь принимать участие в кастингах и даже подписать контракт с самыми именитыми модельными агентствами мира! (AMS);

(32) Мы готовы работать по 25 часов в сутки, чтобы вы смогли обрести уверенность и превратить каждый нюанс своей внешности в неповторимую особенность (AMS).

Оценочные лексемы, используемые в текстах данной разновидности интернет-дискурса, раскрывают ее различные понятийные аспекты, такие, как идеал, принятый в данной сфере деятельности, естественность, усилия по достижению и поддержанию красоты: прекрасный, идеальный, привлекательный, великолепный, блестящие волосы, ухоженные ногти, естественные ногти и т. д.

Интерактивность модельного интернетдискурса, способствующая созданию его воздействующего потенциала за счет использования вопросительно-апеллятивных высказываний, также может рассматриваться в качестве имплицитного выражения ценностной интерпретации красоты тела как руководства к действию:
(33) Попытаем удачу вместе? Друзья, знакомые и просто незнакомые люди часто говорят вам, что вы имеете отличные данные и можете стать моделью? У вас интересное лицо и прекрасная фигура, вы фотогеничны? (KM).

Отрицательная оценка также получает репрезентацию в подобных текстах. Она используется для констатации отрицательных последствий изменения внешности, преследующего квазицель ее эстетизации и усовершенствования, и актуализируется посредством употребления превосходной степени прилагательных, отрицательных местоимений, словинтенсификаторов, усиливающих значение ключевых слов:

(34) Самая страшная ошибка модели - это эксперименты со своим имиджем! Искусственный цвет волос, выщипанные в нить (то есть очень тонкие) брови, наращенные ногти, пирсинги, татуировки, чрезмерный загар. Все это вредит модельной карьере! (ES);

(35) Эти требования абсолютное табу... < ..> И никаких секущихся концов! (ES).

Анализ образного компонента корпореальности концепта «Красота» в текстах, представленных в информационных блоках «Портфолио» на сайтах российских модельных агентств показал, что в большинстве случаев образно-перцептивное восприятие соматических параметров обеспечивается посредством использования иконических знаков, например фотографий моделей, содержащихся в портфолио модельного агентства. Данные иконические знаки обладают значительным воздействующим потенциалом вследствие их наглядности и сходства с объективно существующими моделями [Сорокин, Тарасов, 1990]. Итак, в интернет-дискурсе происходит совмещение двух критериальных систем выражения представлений о корпореальности - специфической для рассматриваемых сфер ценностной картины мира, согласно которой красота осмысляется как своего рода «товар», и медицинской картины мира, постулирующей объективные свойства красоты

\section{Заключение}

Результаты исследования подтверждают зависимость реализации корпореальности как 
признака концепта «Красота» от типа дискурca, в котором он актуализирован.

В медицинском дискурсе понятийную составляющую этого признака формируют представления об основных морфологических параметрах тела, объективируемых посредством терминов, используемых в различных областях медицины. Другим семантическим признаком выступает градуируемость красоты, выражаемая в терминах математических единиц. С позиций медицины красота мыслится как норма, обеспечивающая жизнедеятельность человеческого организма - тела. Такая норма имеет объективный характер, так как обоснована причинно-следственными связями, реализуемыми в телесном бытии. Ценностный аспект корпореальности рассматриваемого концепта реализуется посредством привлечения положительно- либо отрицательнооценочных дескрипторов, указывающих на соответствие / несоответствие тела морфологическому параметру. Образность концепта создается путем креолизации медицинского текста в результате привлечения единиц иного семиотического плана.

Семантическое содержание корпореальной красоты в медико-эстетическом дискурсе более разнопланово и субъективировано. Оно формируется в рамках понятийной дихотомии «отсутствие красоты - ее достижение», признаки, ее реализующие, располагаются на разных оценочных полюсах. Наряду с представлением о красоте как о соответствии морфологической и физиологической норме, в данном дискурсе актуализируются субъективные признаки, такие как изменчивость красоты, ее отчуждаемость и возможность привнесения извне. Ценностная составляющая корпореальности концепта «Красота» выражается посредством соотнесения телесных параметров человека с рядом понятий, положительно оцениваемых в русской лингвокультуpe. В вербализации образной составляющей важную роль играет профессиональное просторечие, а также стилистические приемы, способствующие визуализации смыслового содержания.

В модельном интернет-дискурсе семантическая составляющая корпореальности концепта «Красота» реализуется посредством акцентуации идеальной внешности и сознатель- ных усилий, направленных на достижение принятого в данной сфере идеала красоты, молодости и естественности. Понятие красоты семантически ассоциировано с возможностью достижения успеха. Ценностная составляющая концепта «Красота» в этой разновидности интернет-дискурса выражается посредством как положительной, так и отрицательной оценки. Кроме того, оценочность корпореального признака может выражаться имплицитно.

Образно-перцептивная репрезентация телесных параметров в интернет-дискурсе осуществляется посредством иконических знаков, обладающих высоким апеллятивным потенциалом.

Полученные в работе выводы об особенностях дискурсивной репрезентации корпореальности в структуре концепта «Красота» расширяют представления о картине мира, отраженной в русской лингвокультуре. Они могут быть использованы для объяснения закономерностей вербального поведения людей при оценке объектов эстетического восприятия, а также для облегчения межкультурного взаимодействия.

\section{СПИСОК ЛИТЕРАТУРЫ}

Ахнина К. В., Куриленко В. Б., 2015. Сетевой медицинский дискурс: сущность, признаки, структура // Вестник Российского университета дружбы народов. Серия: Вопросы образования: языки и специальность. № 1. С. 76-84.

Карасик В. И., 2001. О категориях лингвокультурологии // Языковая личность: проблемы коммуникативной деятельности : сб. науч. тр. Волгоград : Перемена. С. 3-16.

Колышкина Т. Б., Шустина И. В., 2015. Восприятие концепта «красота» различными группами участников рекламной коммуникации // Вестник Томского государственного университета. Филология. № 6 (38). С. 46-54. DOI: 10.17223/ 19986645/38/4.

Михеев А. Е., Горбунов П. А., 2012. Интернет и сохранение здоровья // Врач и информационные технологии. № 1. С. 6-16.

Окунева И. О., 2008. Прототипы и стереотипные представления о красоте человека в системе устойчивых сравнений русского и английского языков // Вестник Воронежского государственного университета. Серия: Лингвистика и межкультурная коммуникация. № 3. C. $100-108$. 
Пивоварчик Т. А., 2018. Сетевой медицинский дискурс: коммуникативные практики тематических интернет-сообществ // Вестник Воронежского государственного университета. Серия: Филология. Журналистика. № 4. С. 148-155.

Саидова 3. Э., 2016. Феномен креолизации текста в сетевом дискурсе // Молодой ученый. № 10 (144). C. 1490-1493.

Сорокин Ю. А., Тарасов Ю. Ф., 1990. Креолизованные тексты и их коммуникативная функция // Оптимизация речевого воздействия / отв. ред. Р. Г. Котов. М. : Наука. С. 180-186.

Черкашина Е. А., 2014. Концепт «Красота» в русском языке // Вестник Таганрогского государственного педагогического института им. А.П. Чехова. № 2. С. 38-43.

Zhura V. V., Rudova Yu. V., Martinson Zh. S., 2017. Narrative Continuum of Corporeal Culture $/ /$ Proceedings of the $7^{\text {th }}$ International Scientific and Practical Conference "Current Issues of Linguistics and Didactics: The Interdisciplinary Approach in Humanities" (CILDIAH 2017). Vol. 97. P. 342-347. DOI: https://doi.org/10.2991/ cildiah-17.2017.60.

\section{ИСТОЧНИКИ}

ВКМЭЦ-Врачебная косметология. Медико-эстетический центр. URL: http://www.vr-cosmetology. $\mathrm{ru} /$ kosmetology/inkos.

ВМЭЦ - Вирго. Медико-эстетический центр. URL: http://virgo-khv.ru/

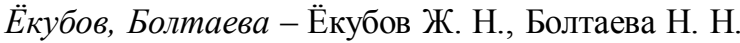
Основные морфологические признаки, определяющие внешнюю форму человека // Наука и образование сегодня. 2016. № 3 (4). С. 42-43.

Иваницкий - Иваницкий М. Ф. Анатомия человека (с основами динамической и спортивной морфологии) : учеб. для ин-тов физ. культуры. Изд. 7-е. М. : Олимпия, 2008. 624 с.

Королев и др. - Королев А. И., Фищев С. Б., Севастьянов А. В., Орлова И. В., Багомаев Т. С. Особенности строения гнатической части лица у детей с физиологической окклюзией постоянных зубов и уменьшением высоты гнатической части лица // Современные наукоемкие технологии. 2014. № 6. С. 80-83.

Негашева - Негашева М. А. Морфологические особенности строения головы и лица у различных конституциональных типов мужчин и женщин // Вопросы антропологии. 1998. Вып. 89. С. 81-90.

Филимонова и др. -Филимонова 3. А., Краюшкин А. И., Перепелкин А. И., Сопит Т. П. Эстетика математики в анатомии человека (золотое сече- ние, логарифмическая спираль, биосимметрия) // Волгоградский научно-медицинский журнал. 2017. №4 (56). С. 17-23.

Хльюбов-Хлыбов В. С., Краюшкин А. И., Пикалов М. А. Анатомия лица в мире эстетической и пластической хирургии : учеб. пособие. Волгоград : Изд-во ВолгГМУ, 2012. 80 с.

Цыганков, Овсянников - Цыганков Б. Д., Овсянников С. А. Психиатрия. Руководство для врачей. М. : ГЭОТАР-Медиа, 2011. 492 с.

$A M S$-Avant Models School. URL: http://avantschool.ru/

$B M$ - Brio Models. URL: https://agency.moda.

$E S$ - Elite Stars. Модельное агентство. URL: https:// www.elitestars.ru/model.

GMS - Grace Models School. URL: http://gracemodels.com/model_school\%20.html.

$K M$ - Krasnadevitsa Models. URL: http://www. krasnadevitsa.ru.

$L A$ - Lege Artis. Клиника эстетической медицины. URL: http://www.l-a.ru/news/3494.

$R M M$ - Renessans Model Management. URL: http:// www.renessans.ru.

$S$ - Sigma. Модельное агентство. URL: https:// sigmascouting.ru.

\section{REFERENCES}

Akhnina K.V., Kurilenko V.B., 2015. Setevoy meditsinskiy diskurs: sushchnost, priznaki, struktura [Medical Net-Discourse: Essence, Qualities, Structure]. Vestnik Rossiyskogo universiteta druzhby narodov. Seriya: Voprosy obrazovaniya: yazyki i spetsialnost [RUDN Journal of Language Education and Translingual Practices], no. 1, pp. 76-84.

Karasik V.I., 2001. O kategoriyakh lingvokulturologii [On Linguocultural Categories]. Yazykovaya lichnost: problemy kommunikativnoy deyatelnosti: sb. nauch. tr. [Homo Communicans: Communication Challenges. Collection of Research Papers]. Volgograd, Peremena Publ., pp. 3-16.

Kolyshkina T.B., Shustina I.V., 2015. Vospriyatiekontsepta «krasota» razlichnymi gruppami uchastnikov reklamnoy kommunikatsii [The Perception of the Concept "Beauty" in Different Groups of Advertising Communication Participants]. Vestnik Tomskogo gosudarstvennogo universiteta. Filologia [Tomsk State University Journal of Philology], no. 6(38), pp. 46-54. DOI: 10.17223/ 19986645/38/4.

Mikheev A.E., Gorbunov P.A., 2012. Internet i sokhranenie zdorovya [The Internet and Keeping Healthy]. Vrach $i$ informatsionnye tekhnologii [Information Technologies for the Physician], no. 1, pp. 6-16. 
Okuneva I.O., 2008. Prototipy i stereotipnye predstavleniya o krasote cheloveka $\mathrm{v}$ sisteme ustoychivykh sravneniy russkogo i angliyskogo yazykov [Prototypes and Stereotype Conception of Beauty Viewed Through the System of Similes of the Russian and English Language]. Vestnik Voronezhskogo gosudarstvennogo universiteta. Seriya: Lingvistika i mezhkulturnaya kommunikatsiya [Proceedings of Voronezh State University. Series: Linguistics and Intercultural Communication], no. 3, pp. 100-108.

Pivovarchik T.A., 2018. Setevoy meditsinskiy diskurs: kommunikativnye praktiki tematicheskikh internet-soobshchestv [Network Meical Discourse: Communicative Practice Thematic Internet Communities]. Vestnik Voronezhskogo gosudarstvennogo universiteta. Seriya: Folologiya. Zhurnalistika [Proceedings of Voronezh State University. Series: Philology. Journalism], no. 4, pp. 148-155.

Saidova Z.E., 2016. Fenomen kreolizatsii teksta v setevom diskurse [The Phenomenon of Text Creolization]. Molodoy uchenyy [Young Scientist], no. 10 (144), pp. 1490-1493.

Sorokin Yu.A., Tarasov Yu.F., 1990. Kreolizovannye teksty i ikh kommunikativnaya funktsiya [Creolized Texts and Their Communicative Function]. Kotov R.G., ed. Optimizatsiya rechevogo vozdeystviya [Optimization of Linguistic Manipulation]. Moscow, Nauka Publ., pp. 180-186.

Cherkashina E.A., 2014. Kontsept «Krasota» v russkom yazyke [The Concept of Beauty in the Russian Language]. Vestnik Taganrogskogo gosudarstvennogo pedagogicheskogo instituta im. A.P. Chekhova, no. 2, pp. 38-43.

Zhura V.V., Rudova Yu.,V., Martinson Zh.S., 2017. Narrative Continuum of Corporeal Culture. Proceedings of the $7^{\text {th }}$ International Scientific and Practical Conference "Current Issues of linguistics and Didactics: The Interdisciplinary Approach in Humanities" (CILDIAH 2017), vol. 97,pp. 342-347. DOI: https://doi.org/10.2991/ cildiah-17.2017.60.

\section{SOURCES}

Vrachebnaya kosmetologiya. Mediko-esteticheskiy tsentr [Medical Cosmetology. Medical and Aesthetic Center]. URL: http://www.vrcosmetology.ru/kosmetology/inkos.

Virgo. Mediko-esteticheskiy tsentr [Virgo. Medical and Esthetic Center]. URL: http://virgo-khv.ru/.

Ekubov Zh.N., Boltaeva N.N. Osnovnye morfologicheskie priznaki opredelyayushchie vneshnyuyu formu cheloveka [The Main Morphological Features Specifying the Exterior Shape of the Human Body]. Nauka $i$ obrazovanie segodnay [Science and Education Today], 2016, no. 3 (4), pp. 42-43.

Ivanitskiy M.F. Anatomiya cheloveka (s osnovami dinamicheskoy i sportivnoy morfologii) ]: ucheb. dlya in-tov fiz. kultury [Human Anatomy: Basics of Dynamic and Sport Morphology. Textbook for Institutes of Physical Education]. Moscow, Olimpiya Publ., 2008. 624 p.

KorolevA.I.,Fishchev S.B., Sevastyanov A.V., Orlova I.V., Bagomaev T.S. Osobennosti stroeniya gnaticheskoy chasti litsa u detey s fiziologicheskoy okklyuziey postoyannykh zubov i umensheniem vysoty gnaticheskoy chasti litsa [The Structure of the Mandible in Children with Physiologic Occlusion in the Primary Dentition and Reduced Hight of the Mandibular Bone]. Sovremennye naukoemkie tekhnologii [Modern High Technologies], 2014, no. 6, pp. 80-83.

Negasheva M.A. Morfologicheskie osobennosti stroeniya golovy i litsa u razlichnykh konstitutsionalnykh tipov muzhchin i zhenshchin [Morphological Features of the Head and Face Structure in Males and Females with Different Types of Body Constitution]. Voprosy antropologii, 1998, vol. 89, pp. 81-90.

Filimonova Z.A., Krayushkin A.I., Perepelkin A.I., Sopit T.P.Estetika matematiki v anatomii cheloveka (zolotoe sechenie, logarifmicheskaya spiral, biosimmetriya) [Aesthetics of Mathematics in Human Anatomy (Golden Section, Logarithmic Spiral, Biosymmetry)]. Volgogradskiy nauchnomeditsinkiy zhurnal [Volgograd Journal of Medical Research], 2017, no. 4 (56), pp. 17-23.

Khlybov V.S., Krayushkin A.I., Pikalov M.A. Anatomiya litsa $v$ mire esteticheskoy $i$ plasticheskoy khirurgii: ucheb. posobie [Facial Anatomy in Aesthetic and Plastic Surgery. Handbook]. Volgograd, Izd-vo VolgGMU, 2012.80 p.

Tsygankov B.D., Ovsyannikov S.A. Psikhiatriya. Rukovodstvo dlya vrachey [Psychiatry. Handbook for Physicians]. Moscow, GEOTARMedia Publ., 2011. 492 p.

Avant Models School. URL: http://avantschool.ru/.

Brio Models. URL: https://agency.moda/.

Elite Stars. Modelnoe agentstvo [Elite Stars. Modeling Agency]. URL: https://www.elitestars.ru/model/.

Grace Models School. URL: http:/grace-models.com/ model_school\%20.html.

Krasnadevitsa Models. URL: http://www. krasnadevitsa.ru/.

Lege Artis. Klinika esteticheskoy meditsiny [Lege Artis. Medical and Esthetic Clinic]. URL: http:// www.l-a.ru/news/3494/. 


\section{РАЗВИТИЕ И ФУНКЦИОНИРОВАНИЕ РУССКОГО ЯЗЫКА}

Renessans Model Management. URL: http://www. renessans.ru/.
Sigma. Modelnoe agentstvo [Sigma. Modeling Agency].URL: https://sigmascouting.ru/.

\section{Information about the Authors}

Viktoriya V. Zhura, Doctor of Sciences (Philology), Associate Professor, Head of the Department for Modern Languages with a Course of Latin, Volgograd State Medical University, Pavshikh Bortsov Sq., 1, 400131 Volgograd, Russia, vvzhura@gmail.com, https://orcid.org/0000-0002-8128-701X

Yuliya V. Rudova, Candidate of Sciences (Philology), Associate Professor, Department for Modern Languages with a Course of Latin, Volgograd State Medical University, Pavshikh Bortsov Sq., 1, 400131 Volgograd, Russia, juliarud@inbox.ru, https://orcid.org/0000-0001-7722-6831

\section{Информация об авторах}

Виктория Валентиновна Жура, доктор филологических наук, доцент, заведующая кафедрой иностранных языков с курсом латинского языка, Волгоградский государственный медицинский университет, пл. Павших борцов, 1, 400131 г. Волгоград, Россия, vvzhura@gmail.com, https://orcid.org/0000-0002-8128-701X

Юлия Владимировна Рудова, кандидат филологических наук, доцент кафедры иностранных языков с курсом латинского языка, Волгоградский государственный медицинский университет, пл. Павших борцов, 1, 400131 г. Волгоград, Россия, juliarud@inbox.ru, https://orcid.org/0000-0001-7722-6831 